DOI 10.37882/2223-2982.2021.11.16

\title{
СРАВНИТЕЛЬНЫЙ АНАЛИЗ РЕАЛИЗАЦИИ НАЦИОНАЛЬНОЙ ПОЛИТИКИ СОВЕТСКОЙ ВЛАСТИ В 1920-Е ГГ. В БАШКИРИИ И ЧЕЧНЕ
}

\section{COMPARATIVE ANALYSIS OF THE IMPLEMENTATION OF THE NATIONAL POLICY OF THE SOVIET GOVERNMENT IN THE 1920S IN BASHKIRIA AND CHECHNYA}

\section{P. Kulchitskiy}

Summary: The task of the author is to try to find specific features in the implementation of the national policy of the Soviet government in the 1920s in Chechnya and Bashkiria. After the establishment of the Soviet power in Russia, the Bolsheviks faced a number of problems in the field of national policy, one of which was the lack of support in national areas. In this regard, at the $X$ Congress of the Party, it was decided to continue the process of the Sovietization of the national outskirts. The national party nomenclature was to become the conductor of the policy of the Soviet power. But to achieve this aim, time was needed, which the Bolsheviks did not have. Therefore, the author considers the unification of national regions with Russian-speaking provinces as an attempt to accelerate this process at the expense of the Russian-speaking proletariat and party nomenclature, designed to promote the Sovietization in the regions.

Keywords: national questions, national outskirts, $X$ congress of the $\mathrm{RCP}(\mathrm{b})$, Ufa province, Malay Bashkiria, Grozny, Chechnya.
Кульчицкий Петр Викторович Учитель, МБОУ Гимназия №11 petrkulchitskii@yandex.ru

Аннотация: Задачей автора является попытка поиска особенностей в реализации национальной политики советской власти в 1920- е гг. в Чечне и Башкирии. После установления Советской власти в России большевики столкнулись с рядом проблем в области национальной политики, одна из них заключалась в отсутствии опоры в национальных областях. В связи с этим на $X$ съезде партии было принято решение о продолжении процесса советизации национальных окраин. Проводником политики советской власти должна была стать национальная партийная номенклатура. Но для достижения поставленной цели было необходимо время, которого у большевиков не было. Поэтому объединение национальных областей с русскоязычными губерниями автор рассматривает как попытку ускорения этого процесса за счет русскоязычного пролетариата и партийной номенклатуры, призванных содействовать советизации в регионах.

Ключевые слова: национальный вопрос, национальные окраины, X съезд РКП(б), Уфимская губерния, Малая Башкирия, Грозный, Чечня. о окончании Гражданской войны перед большевиками встал ряд важных задач. Наиважнейшей из них было восстановление промышленного производства в центральных областях страны и успокоение деревни. Кроме того, советская власть в национальных областях не обладала политическим весом и проводниками идей и власти большевиков являлись представители местной интеллигенции, лояльные советской власти. Но этот союз был для большевиков лишь временной альтернативой, так как национальная элита в восприятии большевиков была «классово чуждым элементом». К примеру, Али Митаев был шейхом, а весь Башревком до 16 февраля 1919 г. был на стороне белых. Делать ставку на подобные чуждые элементы в длительной перспективе было бы недальновидным решением со стороны большевиков.

Поэтому после завершения Гражданской войны на основной территории страны на Х съезде РКП(б), состоявшемся в марте 1921 г., проблемам национальной по- литики было уделено серьезное внимание. На заседании с докладом по национальному вопросу выступал глава Наркомнаца И.В. Сталин. Среди прочих задач он назвал в качестве важнейшей ликвидацию неравномерности развития национальных окраин по сравнению с центральными регионами. В связи с этим было принято постановление «Об очередных задачах партии в национальном вопросе» [14, с.62]. Основу регионального руководства, исходя из постановления, должны были составлять представители местных национальностей. Это, в свою очередь, требовало подготовки квалифицированных партийных кадров, которых на окраинах страны, в том числе в Башкирии и на Северном Кавказе, было крайне мало. Преобладание родоплеменных отношений, значительное влияние религии на местное население, проживающее на указанных территориях; аграрно-кустарные формы занятости населения не содействовали росту общественного сознания и общему уровню культуры местного населения. Поэтому для подготовки партийных кадров в национальных областях было необходимо раз- 
вивать сеть школ, в том числе профессионально - технического характера. Эту задачу съезд утвердил в качестве первостепенной [14, с.62].

Для выполнения постановления было необходимо время, а учитывая слабость большевиков в национальных областях, реализация постановлений X съезда могла столкнуться с трудностями.

В Чечне местная интеллигенция не имела значительного веса в архаичном обществе, где было велико влияние ислама. Поэтому большевикам и пришлось выстраивать отношения с шейхами, например Али Митаевым. Партийная ячейка Чечни не имела на тот момент ресурсов для пополнения: представители чеченской элиты были в основном сторонниками архаичных шейхов или мулл либо не стремились вступать в РСДРП(б), видя в ней продолжателя политики русского царизма на Северном Кавказе. Кроме того, определенная часть автохтонного населения Северного Кавказа к русскому языку и культуре относилась с определенным недоверием [1, с. 275]. А представители этнических сообществ, согласившихся сотрудничать с большевиками и занявшие руководящие посты в системе аппарата управления, рассматривались как чуждые элементы, потерявшие связь со своим этносом $[13$, с. 38].

Кроме того, партийную организацию Чечни раздирали конфликты, основанные на борьбе фракций, созданных исходя из кровного родства. По принципу кровного родства и принимали в Чечне в партию.

Из-за вышеуказанных факторов партийная ячейка Чечни была одной из самых малочисленных на всем Северном Кавказе. По разным оценкам, в Чечне было всего лишь 30 коммунистов [3, с. 115].

Поэтому большевики и рискнули на территории Северного Кавказа, особенно в Чечне, заручиться поддержкой некоторых шейхов и мулл. Естественно, религиозные чеченские лидеры, поддержавшие советскую власть, делали это для получения выгоды. К примеру, Али Митаев, став сторонником советской власти, использовал свое положение для получения финансирования своих вооружённых отрядов мюридов, пополнивших ряды чеченской милиции.

Похожая ситуация была и в Башкирии. Отношение к РСДРП(б) также было настороженное. Многие башкиры воспринимали большевиков как русскую партию, куда вступало в основном русскоязычное население, стремящееся захватить башкирские земли $[17$, л. 16,18].

При этом исламское духовенство не играло основополагающей роли в жизни башкир, как это было в Чечне, и поэтому не являлось сильным сдерживающим факто- ром роста партийной ячейки Башкирии.

Кроме того, более многочисленная, чем чеченская, партийная организация Башкирии сформировалась на основе национального движения еще до Октябрьской революции. При этом оно было целостным, лидеры башкирского национального движения выступали единым фронтом, а его центральные фигуры, например С.Г. Мрясов, А.Н. Ягафаров, имели политический опыт и принимали участие еще в I Всероссийском мусульманском съезде мая 1917 г.

В Чечне же, как таковое не было сформировано единое национальное движение, а были отдельные политические силы из шейхов и мулл, часто враждовавших еще и между собой.

Соответственно, с установлением в данных областях советской власти большевики и в Башкирии могли на первых порах сделать ставку на местную интеллигенцию, лояльную им после заключения соглашения между советской властью и башкирским правительством в марте 1919 г.

Конечно, после январского конфликта 1920 г. между Башревкомом и Башобкомом и последующего за этим самороспуска Башревкома многие башкирские партработники последовали примеру представителей ревкома и покинули свои посты. Но часть партработников все же осталась работать на стороне советской власти.

Таким образом, к 1922 г. в Башкирии было 3809 человек, являвшихся коммунистами, но татар и башкир из них было всего лишь 17 и 16\% соответственно [10, с. 282].

Могло определённую роль в столь незначительной численности башкир сыграть и постановление советской власти «О государственном устройстве Автономной Советской Башкирской Республики» от 20 мая 1920 г., урезавшее самостоятельность башкирской автономии. Постановление стало одним из факторов, вызвавшим разочарование башкир в советской власти и, соответственно, нежелание последних вступать в партию. Соответственно, авторитет новой власти в глазах башкир был незначителен [4, с. 123].

В столь непростой ситуации для большевиков огромную помощь в советизации данных областей оказывали крупные экономические и политические центра - Грозный и Уфа.

В Уфе и Грозном существовала значительная по численности ячейка партии большевиков. Численность Уфимской парторганизации к 1922 г. составляла 5374 человек, Грозненская партийная организация включала в себя 1200 человек [9, с. 16.] [10, с. 282]. 
Безусловно, партийная ячейка Малой Башкирии, как отмечалось ранее, была значительна по численности, но недавний конфликт Башревкома с башкирским обкомом показал советской власти, что за Малой Башкирией необходим контроль. Конечно, еще в 1921 г. партийный аппарат Малой Башкирии был основательно очищен от ненадежных элементов, сочувствующих национальному движению А. Валидова. Всего по итогам чистки из партии было исключено 32\% члена и кандидата в члены партии [4, с. 146]. Но для установления полного контроля над башкирской партийной ячейкой было необходимо объединить область с крупным политическим центром Южного Урала. Уфа, учитывая еще и давние тесные экономические связи, для этого подходила лучше всего.

Кроме того, Малая Башкирия серьезно пострадала из-за голода 1921-1922 гг., не имела железных дорог, средств связи и даже столицей ее был Стерлитамак, переданный башкирам как временная альтернатива. 6 из 13 кантонов находились вдали от центральных областей Башкирии, тем самым территория была в буквальном смысле разделена другими областями и автономными образованиями [6, с. 215].

Из всего вышесказанного можно было сделать вывод, что для нормального существования Малой Башкирии было необходимо объединить ее с Уфимской губернией.

Сама идея объединения двух областей не была сугубо инициативой Москвы. Представители Малой Башкирии в своих планах определили ряд территорий, которые, по их мнению, должны были стать частью Башкирии. К этим территориям относились Златоустовский горнозаводской район, район горы Магнитной, а также вся Уфимская губерния и все башкирские волости Мензелинского уезда. Также по плану башкирской стороны в состав республики должен был войти Оренбург [8, с. 731].

В итоговом документе, отправленном в столицу, Оренбург не значился. Скорее всего, башкирское руководство не решилось включать в документ данный город, опасаясь отрицательной реакции в Москве.

Оренбург, построенный на стыке казахских степей и башкирских земель, являлся одним из главнейших промышленных центров Южного Урала. Передача его в состав БАССР вызвала бы неоднозначную реакцию не только в среде оренбургских коммунистов, отношения которых к автономии башкир было враждебное, но и среди высших эшелонов РСДРП(б).

Итоговый декрет был принят 14 июня 1922 г., и по нему Уфимская республика упразднялась и входила в состав Башкирии вместе с Бирским, Златоустовским и Белебеевским уездами. Но в то же время от Башкирии отходил Яланский кантон. Столицей становился город Уфа [5, с. 153-154].

Стоит заметить, что кроме Яланского кантона от новообразованной республики отошли девять волостей Уфимского уезда, восемнадцать волостей Тамьян-Катайского уезда, три волости Миасского уезда. В данных волостях было развито металлургическое производство. Эти волости были переданы Уральской области.

После неоднократных жалоб БашЦИКа в Москве пошли на встречу БАССР и оставили в ее составе Тамьян-Катайский уезд. Но находящиеся в этом уезде Белорецкие предприятия подчинялись уральской промышленности [8, с. 776]. В дальнейшем, в 1927 г. Белорецкие заводы будут выделены в самостоятельное хозяйственное объединение, не подчиненное Уральское области [6, с. 231].

В целом, это очень хорошо показывало, что в Москве не планировали отдавать в подчинение национальной республике стратегическое производство.

Само объединение Уфимской губернии и БАССР в единую республику, позволило не только установить контроль над БАССР и ее партийной ячейкой, но и экономически поднять уровень губернии. Но сама идея увеличить численность партийной ячейки БАССР за счет националов не была отброшена полностью. Советская власть на XIII съезде партии, прошедшем в Москве в мае 1924 г., постановила, что для восточных республик и автономных областей Северного Кавказа необходим облегченный прием в партию. Также необходимо переводить из кандидатов в члены партии крестьян, батраков, кустарей [8, с. 223-224]. Для реализации этого постановления продолжали работать совпартшколы, созданные еще по решению Х съезда партии. В этих школах и кружках БАССР к 1924-1925 гг. занималось до 4432 тысяч человек [18, л.61]. Немаловажную роль играли различные секции и комиссии при горсоветах, волисполкомах и сельсоветах. Эти низовые органы власти прорабатывали вопросы, которые затем уже шли на рассмотрение исполкомов Советов.

Все это позволило к началу 1930 - х гг. увеличить партийную ячейку БАССР за счет тюркоязычного населения, но незначительно. К 1929 г. башкиры и татары составляли 17 и 21\% партийных работников соответственно [16, c. 147].

Много факторов оказывало влияние на столь низкую статистику по партийным работникам из числа татар и башкир. К примеру, часты были случаи, когда секции и комиссии, обязанные привлекать к работе в низовых органах власти представителей тюркоязычного населения, задействовали их только на бумаге. 
Но все же для советской власти самым главным аспектом было то, что башкирская партийная ячейка теперь объединена с уфимской, которая была более лояльна Москве. Уфимские коммунисты теперь могли держать под контролем своих башкирских коллег. При этом были проведены партийные чистки не только до объединения, но и после объединения БАССР и Уфимской губернии. Масштаб чистки не был столь значителен, как в 1921 г., но его целью было не только очищение от остатков «валидовщины», но и чистка партии от сторонников М.Х. Султан - Галиева, исключенного за национал-уклонизм.

В отношении Чечни советская власть приняла схожие решение, но в первой половине 1920 - х гг. объединение Грозного и Чечни не было возможно из-за слабости советской власти в Чечне. К примеру, в Чечне несколько раз возвращались к системе ревкомов: в августе 1921 г. и в июле 1922 г. Советская печать объясняла это культурной отсталостью местного населения, заселием мулл и шейхов, мешающих проведению политики советской власти в Чечне.

К 1924 г. ситуация изменилась. Советская власть в Чечне почувствовала себя увереннее. Подтверждает этот вывод арест и расстрел одного из членов ревкома Чечни и влиятельного шейха Али Митаева в 1924 г.

Уже в 1925 г. большевики приняли решение провести не только масштабную акцию по разоружению населения, но и партийную чистку. Пленум Чеченского облисполкома выявил «отсутствие твердого и умелого руководства Соваппаратом» и обвинил в этом Эльдарханова. Эльдарханов был снят с должности председателя Чеченского облисполкома.

В Чеченский исполком пришли лояльные воле Москвы партийные работники: М. Энеев, А. Саламов, А. Сайханов и др. Главой Чеченского исполкома стал Д. Арсанукаев [19, л. 26 об; 27 об].

Как и в БАССР, в Чечне не только с помощью чисток советская власть укрепляла свое положение. К примеру, на Чечню тоже распространялось постановление XIII съезда партии, в котором отмечалось, что для данных областей необходим облегченный прием в партию. Кроме того, на Северном Кавказе планировалось организовать при избах-читальнях кружки для политической подготовки, привлекать возможных кандидатов в партию к работе в советских профсоюзных и кооперативных организациях. По мере появления новых кадров, преданных советской власти, можно было начать процесс очищения руководящих органов от «идеологически чуждых компартии элементов» [2, с. 42].

Но принятые меры не принесли значительных результатов. К 1926 г. в Чечне численность партийной орга- низации выросла с 40 до 632 партийцев [9, с. 16].

Говорить о быстрой советизации со столь незначительным увеличением партийной ячейки Чечни было сложно. К тому же, резолюции XIII съезда не могли решить проблему клановости в партийных кругах области. Рядом же, как отмечалось ранее, находился крупный экономический и политический центр город Грозный, который мог возглавить советизацию автономной области.

Партийная чистка 1925 г. и замена своенравного руководства Чечни более покорным открыла возможность Москве реализовать свои планы по объединению Грозного и Чечни в составе одной республики.

Процесс был начат в 1928 г. В ноябре этого года крайисполком издал постановление о ликвидации Сунженского и Грозненского автономных округов и объединения их с Чечней.

Стоит отметить, что так же, как и при объединении БАССР с Уфой, обсуждения с руководством Грозного вопроса объединения с Чечней не было. Соответственно, постановление предусматривало начало широкой пропагандисткой компании, что вполне могло означать опасение со стороны советского руководства за успех данной компании.

Но, для большевиков было в приоритете выполнение задач, стоявших перед партией, поэтому мнение противников объединения выслушивалось, но на финальное решение оно никак не влияло.

К тому же, польза от объединения для Москвы была значительна. По мнению ответственного секретаря Чеченского областного комитета ВКП(б) Г.О. Булата, слияние Чечни и Грозного позволило увеличить количество коммунистов до 6 тысяч, а комсомольцев до 10 тысяч человек на полумиллионное население области [11, с. 60]. Объединение Грозного и Чечни дало советскому руководству основание для пополнения партийного и хозяйственного руководства русскоязычными работниками, усилив при этом советизацию самой Чечни.

При этом на существующие взаимоотношения между «Грознефтью» и Чеченской ав ᄀтономной областью остались без изменений. «Грознефть» продолжала управляться напрямую из Москвы. Это очень напоминало решение советской власти в отношении Белорецких заводов и Башкирии, где так же, как и в Чечне, центр не захотел отдавать под управление новой республики стратегические предприятия.

В целом действия советской власти по объединению русскоязычных политических и экономических центров 
с национальными областями означали шаг к изменению В национальной политике. Как отмечал историк А.Н. Щербак, для форсированного строительства социализма было необходимо усиление роли национального большинства - русских [15, с. 121]. К тому же, для большевиков главным являлось максимально быстрое формирование наций, которые в дальнейшем растворятся в неизбежном движении человечества к коммунизму [7, с. 99].

Разгромив в Гражданской войне контрреволюционные силы, большевики обратили внимание на национальную политику, дабы укрепить свою власть в национальных областях. Для достижения этой цели было необходимо развивать и укреплять местную лояльную советской власти партийную номенклатуру.

Партийная ячейка большевиков в национальных областях была незначительна по численности. Господство исламского духовенства, низкий уровень образования, недоверие к РСДРП(б) - все эти факторы сказывались на росте численности местных партийных ячеек.

Укрепление партийного аппарата требовало времени, которого у РСДРП(б) не было. Периодические смены советов на ревкомы в Чечне и конфронтация Башревкома с башкирским обкомом ярко показали советской власти, что надеяться на местную элиту в длительной перспективе не стоит. Для ускорения советизации было принято решение объединить русскоязычную Уфимскую губернию с БАССР, а Грозный - с Чечней.

При этом это позволило бы ускорить и экономическое выравнивание областей с русскоязычным центром.

Процесс объединения не вызывал одобрения у партийных структур Уфы и Грозного, но большевики были партией, где было строгое подчинение мнению центра. Поэтому серьезного сопротивления идеи объединения Уфы с Башкирией и Грозного с Чечней не было.

Процесс объединения БАССР с Уфой начался намного раньше: в начале 1920-х гг. Для БАССР объединение было жизненно важным этапом. В республике отсутствовала нормальная транспортная система, и даже роль столицы выполнял Стерлитамак, который советская власть передала башкирам ранее, в 1919 г.

Кроме того, очень удачно для Москвы, Башревком решил самоустраниться после неудачного для них развития конфликта с Башобкомом в начале 1920 г. В 1921 г. была проведена основательная чистка партийных рядов БАССР. Таким образом, для объединения Уфы и Башкирии было самое подходящие время.

В Чечне ситуация была намного сложнее: очень сла- бая партийная ячейка, серьезное влияние на население оказывали духовные лидеры. Отсюда и максимально гибкая политика Москвы в первой половине 1920- х гг. Только арест и расстрел Али Митаева, одного из крупнейших лидеров чеченцев, показал, что советская власть окрепла и может перейти к ужесточению своей политики в автономии.

Но, кроме наступления на лояльную большевикам местную элиту, было решено по итогам XIII съезда, начать облегченный прием в партию для восточных республик и автономий Северного Кавказа. Также были организованы при избах-читальнях кружки для политической подготовки, привлекались кандидаты в партию и к работе советских профсоюзных организаций и пр. Это показывало, что советская власть не отказалась от идеи создать из местного населения лояльную Москве партийную верхушку для национальных областей и республик.

В обеих рассматриваемых областях рост в целом был незначительный, но в отношении Чечни это стало дополнительным доводом в пользу объединения Грозного и автономной области. Закончить советизацию в Чечне, имея столь незначительную опору в автономии, было очень сложно.

Соответственно, после партийной чистки, проведенной в 1925 г. и устранения старой партийной номенклатуры в лице Т. Эльдарханова, можно было переходить к объединению.

И для БАССР, и для Чечни объединение сыграло положительную роль. Для Башкирии, перенесшей серьезный голод 1921-1922 гг., объединение было жизненно важным событием. Обновленная республика не только включила в себя большую часть территорий, населенных башкирами, но и объединила в себе промышленный потенциал Уфимской губернии и ресурсную базу Башкирии.

Для Чечни также решался важный экономический вопрос: Грозный являлся одним из крупнейших экономических центров Северного Кавказа, имевшим развитую промышленность. Объединение с ним позволило не только соединить промышленный потенциал Грозного и нефтяные ресурсы Чечни, но и разрешить давний территориальный спор города и автономии.

Но в то же время в обоих случаях объединение увеличило партийные ячейки за счет русскоязычного населения. Это было выгодно большевикам. С увеличением числа русскоязычных работников в партийном аппарате национальных регионов увеличился и контроль со стороны Москвы. 


\section{ЛИТЕРАТУРА}

1. Аккиева С.И. Национально- государственное строительство и образовательная политика на Северном Кавказе в 1920-1930-е гг.// Татьяна Павловна Хлынина. In Memorian: сборник статей и материалов. Отв. Ред. Е.Ф. Крринко. Ростов н/Д: ЮНЦ РАНЦ, 2017.

2. Алиева С.И. К вопросу о национальной политике большевиков на Кавказе (1917-1920- ые гг.)// Современная научная мысль. № 5. М.: Научно-исследовательский институт истории, экономики и права, 2017.

3. Сигаури И.М. Очерки истории и государственного устройства чеченцев с древнейших времен. М.: Русь, 2001. с. 371 .

4. Ишемгулов Н.У. Образование Башкирской республики. Уфа: Китап, 2018. с.170.

5. История Башкортостана. В 2-х томах. Т. 1. 1917-1945. Уфа: Гилем, 2004. с. 400.

6. Касимов С.Ф. Автономия Башкортостана: становление национальной государственности башкирского народа (1917— 1925 гг.). Уфа: Китап, $1997 . c .351$.

7. Кловер Ч. Черный ветер, белый снег. Новый рассвет национальной идеи. М.: Фантом Пресс, 2017. с.493.

8. Коммунистическая партия Советского Союза в резолюциях и решениях съездов, конференций и Пленумов ЦК (1898-1988)/ Под общ. ред. А.Г. Егорова, К.М. Боголюбова. В 16 Т. Т. 3: 1922-1925. М.: Политиздат, 1984. с. 494.

9. Образование Башкирской Автономной Советской Социалистической Республики. Уфа: Башкнигоиздат, 1959.с. 900.

10. Овчаров Г.М. Борьба Чечено-Ингушской партийной организации за победу ленинских идей. (1926-1929 гг.). Грозный: Чечено-Ингуш. кн. изд-во, 1975. c.79.

11. Очерки истории Башкирской организации КПСС. Уфа: Башкир. кн. изд-во, 1973. с.728.

12. От вековой отсталости - к социализму: Сб. документов и материалов //отв. ред. Джугурьянц С.Н. Грозный, 1977.с. 204.

13. Туфанов Е.В. К вопросу об источниках рекрутирования региональных управленцев в 1920 - 1930 - е гг. на материалах Северного Кавказа// Вестник Калмыцкого университета. 37. Элиста: Изд-во Калмыцкого университета, 2018.

14. Шнайдер В.Г. Советское нациестроительство на Северном Кавказе (1917-конец 1950 годов): закономерности и противоречия. Армавир РИЦ АГПУ, 2007. c.414.

15. Щербак А.Н. Болячевиц Л.С, Платонова Е.С. История Советской национальной политики: колебания маятника?!// Политическая организация разделенных обществ. №1. Ред. Составитель И.В. Кудряшова, О.Г. Харитонова. М.: ИНИОН РАН, 2016.

16. Юлдашбаев Б.Х. Новейшая история Башкортостана. Уфа: Китап, 1995.с. 287.

17. Центральный государственный архив общественных объединений Республики Башкортостан (ЦГАОО РБ. Ф). 22. Оп. 3. Д. 66.

18. Центральный государственный архив общественных объединений Республики Башкортостан (ЦГАОО РБ. Ф). 122. 0п. 4. Д. 87.

19. Государственный архив Российской Федерации (ГАРФ). Ф. 1235. Оп. 120. Д. 116.

(c) Кульчицкий Петр Викторович (petrkulchitskii@yandex.ru). 